\title{
異なるキャンロール温度で成膜された蒸着テープの特性
}

\author{
吉田修, 石川彰*, 水野谷博英, 北折 典之
}

\section{Parformance of Metal Evaporated Tapes Prepared at Different Temperatures of Can Roll}

\author{
Osamu YoshIDA, Akira ISHIKAWA*, Hirohide MIZUNOYA and Noriyuki KITAORI \\ Received February 13, 1998 ; Accepted July 1, 1998
}

Metal evaporated (ME) magnetic tapes were prepared by oblique evaporation method at two different temperatures $\left(-30{ }^{\circ} \mathrm{C}\right.$ and $\left.50{ }^{\circ} \mathrm{C}\right)$ of can roll. Thickness of ME layers was varied between about $50 \mathrm{~nm}$ and $200 \mathrm{~nm}$ at the respective temperatures. The tapes prepared at $50{ }^{\circ} \mathrm{C}$ of can roll showed better output than the tapes prepared at $-30{ }^{\circ} \mathrm{C}$. This was attributed to (1) more magnetic orientation of the ME layers prepared at $50{ }^{\circ} \mathrm{C}$ than the ME layers prepared at $30{ }^{\circ} \mathrm{C}$ and (2) less space loss of output of the tapes prepared $50{ }^{\circ} \mathrm{C}$. The first point (1) was recognized by measurement of angular variation of coercivity. The second point (2) was confirmed by Auger electron spectroscopy. As for thickness of magnetic layer, the ME tape with thickness of around $100 \mathrm{~nm}$ showed the best wavelength dependence of output.

\section{1 粕 言}

磁気記録テープの進化は, 常に高密度化一志向して 変遷してきた ${ }^{1,2)}$ ここれは, ハードウエアであるビデオデッキ のみならず，記録媒体である磁気テープにも当てはまる. 磁性体も，1975年に上市された家庭用ビデオテープ ${ }^{3)}$ おいては，酸化鉄系磁性粉末であり，これを分散させ，心゙ 一スフィルムに固定するために結合剤(榯脂)を用いてい た.しかし，1996年のデジタルVCRでは結合剤のような非 磁性の材料を含まない金属蒸着 $(\mathrm{ME})$ 薄膜媒体一と変わ ってきている ${ }^{4,5)}$.ME媒体は,これまで主流であった塗布 媒体と比心非磁性の材料を含まない点加ら仗究極的な形 態をしていると言える.また，高密度記録の際に必要とさ れる薄膜化が容易に行われる点でも有利である ${ }^{6}$. 通常の ME媒体の磁性層は，斜め蒸着法により成膜され，磁性体 はコラム構造をしている7).このコラムの形成の状態により 磁気特性および電磁変換特性が決定される ${ }^{8,9,10)}$. コラム 形成がなされる面の反対面は, ベースフィルムの変形を抑 花王(株) 栃木研究所 (广321-3497 栃木県芳賀郡市貝町 赤羽 2606） Tochigi Research Laboratories, Kao Corporation (2606, Akabane, Ichikaimachi, Haga, Tochigi, 321-3497, Japan)

Key Words: Magnetic Recording, Evaporation, Vapor Deposition, Can Roll Temperature
えるため冷却用のキャンロールに接しており, 成膜時にこ の場所には通常酸素ガスが導入される.酸素ガス導入の 目的は，酸化と前記の斜內蒸着とを組み合わせることによ り，ME薄膜に磁気記録用に適した大きさの保磁力を付与 することにある.このようにして作製したME薄膜の断面の 透過型電子顥微鏡写真をFig. 1に示寸. Fig. 1上り, 唀曲 した柱状の構造(コラム)が形成されていることが判る.

以上のようにキャンロールの条件はテープ特性に大きな 影響を与えることは明かである. しかし，キャンロールにつ いては, プラスチック製のベースフィルムの変形を抑えるた めに冷却することは言われているが，具体的な温度条件に ついては殆ど報告されていない.

我々はME媒体の磁気特性の向上を求めて成膜条件を 検討しており, 既にME層の厚みと電磁変換特性との関連 について報告した ${ }^{11)}$.

本報では，従来あまり報告例のない上記キャンロールの 温度を変えてMEテープを作製し、テープ特性を評価した 結果を報告する。

なお，磁性材料としては，デジタVCR用のMEテープで 採用されている金属C口在用い ${ }^{4,5)}$, 斜め蒸着法によりME 層を形成した。 


\section{2 实 酸}

\section{1 蒸著テープの作製}

本実騃で用いた連続巻き取り式斜方蒸着装置をFig. 2 に示す. 巻き出されたベースフィルムはキャンロールに沿 つて走行後, 巻き取られる. キャンロール上のベースフィル ムには，電子銃により加熱された坩堝加蒸発した金属蒸 気が蒸着され，金属薄膜 (磁性層: ME層) が形成される. 充分高い保磁力を確保するため ${ }^{6)} \mathrm{ME}$ 層表面に法酸素ガ スを導入した. 本報告ではキャンロールの温度は一 $30^{\circ} \mathrm{C}$, $50^{\circ} \mathrm{C}$ の2 条件であった. 蒸着膜の厚みは心゙ースフィルムの 搬送速度を変えることにより制御した。実際に作製した蒸 着層の厚みは40 nmから200 nmであった。

ベースフィルムは10 $\mu \mathrm{m}$ 厚みのポリエチレンテレフタレー ト(PET)を用い，蒸着金属には，99.9\%純度のCoを用 いた，その他の操作条件をTable 1に示す.

このように蒸着磁性層を形成した後, 走行性を良好にす るため通常の力法 ${ }^{6)}$ で潤滑剂を塗布し，磁性層の裹面に は0. $5 \mu \mathrm{m} の$ 厚みにバックコート畨を塗設した. その後, 得られた磁気テープは $8 \mathrm{~mm}$ 幅にスリットレ, 評価用のテー プサンプルとした.

\section{2 测定}

\section{2.1 磁性層の特性}

磁性層の厚みは Talystep (Rank Taylor Hobson Ltd. 製)により触針・段差法により測定した。磁性層の透 過率は910 nmの波長にて測定した.

磁性層の磁気特性は振動試料式磁力計(VSM)にて, 最大印加磁場を796 kA / m(10 kOe) しLた. 印加磁場 はテープの長手方向と法線を含む面内で Fig.3に示すよう にテープの長手方向と印加磁場と汸す角度 $\theta$ 老変えて測 定した.

磁性層の表面粗さの测定は, ZYGO社製レーザー光干 涉測定用顕微鏡（商品名:Laser Interferometric Microscope Maxim3D Model 5700)にて, Fizeau レンズ40倍を使用し,フィルター(カットオフ波長=0.236 $\mathrm{mm}$ )を入れ行った。なお，測定データは，サンプルを円 筒状曲面とみなして低周波のうねり成分を除去する処理 (シリンダー処理)を行い, 中心線表面粗さRa及び十点平 均表面粗さRzを求めた。

\section{2.2 電磁变换特性}

サンプルテープの電磁変換特性はFig.4に示すような測 定系からなるへッドテスター法により測定した。なおへッド ギャップは0. $22 \mu \mathrm{m}$, テープとーッドとの相対速度は $3.8 \mathrm{~m} / \mathrm{sec}$ であった. また, 記録信号注矩形波であり， 記録電流值は各テープに㧍いて記録波長が0.49 $\mu \mathrm{m}$

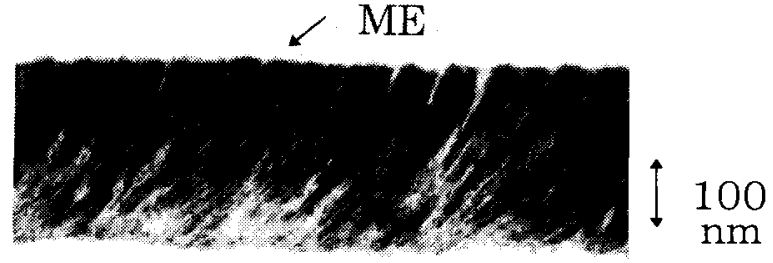

Basefilm

Fig.1 Cross section of metal evaporated layer. ME : Metal evaporated layer Basefilm (PET)

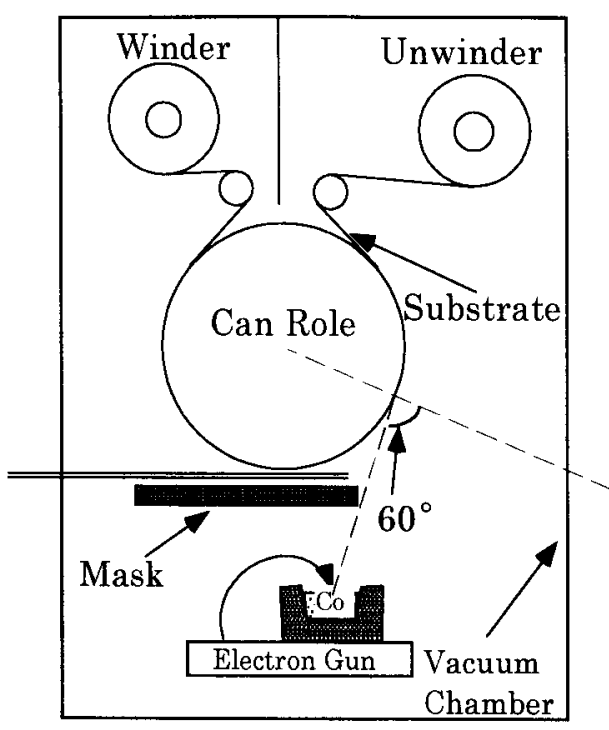

Fig.2 Experimental apparatus used to prepare $\mathrm{ME}$ tape.

Table 1 ME tape preparation conditions.

\begin{tabular}{lc}
\hline Background pressure & $2.67 \mathrm{mPa}$ \\
Oxygen gas pressure & $1.6 \mathrm{mPa}$ \\
EB-gun power & $10 \mathrm{~kW}$ \\
Tape running speed & $0.5 \sim \mathrm{m} / \mathrm{min}$ \\
Angle of incidence & $60^{\circ}$ \\
\hline
\end{tabular}




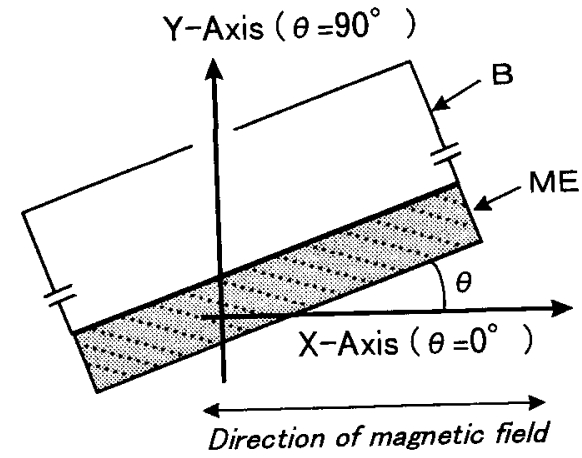

Fig.3 Direction of magnetic field.

ME : Evaporated Magnetic layer.

B : Basefilm (PET).

における最適電流とした. 再生出力はスペクトラムアナライ

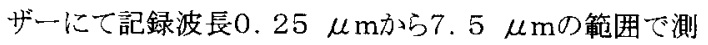
定した.

\section{2. 3 Auger電子分光分析}

Auger電子分光スペクルル, 日本電子 (株) 製の商品 名JAMP－10Sにより，Ar雾囲気にて差動排気型マイクロ イオン銃にてエッチングを行い梁さ方向の分析在行った。 測定条件は以下のとおりであった。

[測定真空度] 最表面分析時: $1 \times 10^{-7} \mathrm{~Pa}$, 深さ方向分 析時: $6 \times 10^{-7} \mathrm{~Pa}$ (Ar雰囲気)

[測定条件] 加速電圧: $3 \mathrm{kV}$, 照射電流: $1 \times 10^{-7} \mathrm{~Pa}$, 試料傾斜角: $70^{\circ}$, ビーム径: $50 \mu \mathrm{m}$, スリリッ:No. 5 [エッチング条件] イオン種: $\mathrm{Ar}^{+}$, 加速電圧: $3 \mathrm{kV}$, 試料 電流: $6 \times 10^{-7} \mathrm{~A}$, エッチング速度: $11 \mathrm{~nm} / \mathrm{min}\left(\mathrm{SiO}_{2}\right.$ の場合)

\section{3 結果と考察}

\section{1 磁性層の特性}

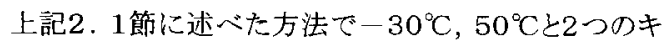
ヤンロール温度条件にてそれぞれ3水準の光逶過率のサ ンプルテープを作製した. 作製したテープの物性をTable 2 にまとめる. 成膜時のキャンロールをー $30^{\circ} \mathrm{C}, 50^{\circ} \mathrm{C} と し$ た場合のいずれもテープの磁性層の表面性はほぼ一定で あった。

ME層の光透過率上膜厚の関係をFig. 5に示す. Fig. 5 では, 膜厚が高くなれば光透過率が減少するが, 同じ膜 厚で比べれば，キャンロール50采の方が光透過率は低い ことが判った。一般に金属を酸化主ると電子密度が低下し 光透過率が高くなる. 従って, よりキャンロール温度が高い

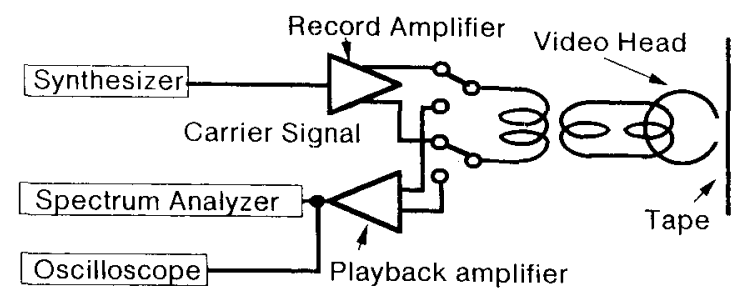

Fig.4 Block diagram of measuring magnetic recording performance.

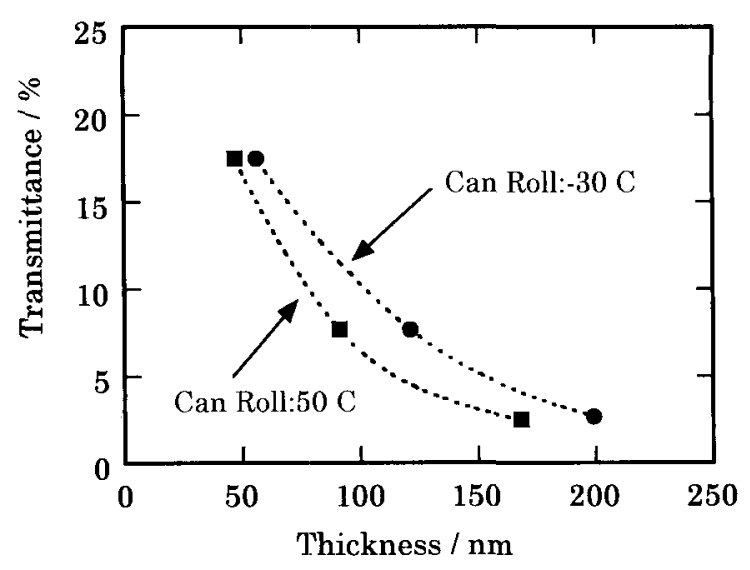

Fig.5 Transmittance against thickness of metal evaporated magnetic layer

$50^{\circ} \mathrm{C}$ 場合のほうが, 酸化層の厚みが薄い上考えられる. 一般に高温の方が酸素之の反応が速くなる点からすれば， 高温の50 $\mathrm{C}$ では，酸化反応は速いと考えてよい，キャンロ 一ル温度が高い場合, 磁性層のコラム表面が充分に酸化 されるため，酸素ガスが消費されてしまい内部への酸化が 進行しない，または生成した酸化膜が遮蔽層となりコラム 内部一の酸化が抑えられる。一方，キャンロール温度の低

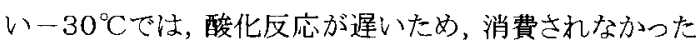
酸素ガスが残り，この酸素がコラム内部一浸透し徐々に酸 化が起こる. 表面も酸化されるが, 内部への酸素の浸透を 抑えるほど緻密な酸化膜ではない.Fig. 5の光透過率に ついては，以上のように考察する。

なお, ここで, 生成する酸化物は一酸化コバルト $(\mathrm{CoO})$ 上 考える. 高山らの検討 ${ }^{12)}$ によれば, $\mathrm{Co}$ 系(Co- $\mathrm{CoO}$ 系) の磁性膜では，酸素ガス考導入した場合，一酸化コバルト が生成することが明かにされている。 
Table 2 Characteristics of Sample Tapes.

\begin{tabular}{|c|c|c|c|c|c|c|c|c|}
\hline \multirow{3}{*}{$\begin{array}{l}\text { Sample } \\
\text { Number }\end{array}$} & \multirow{3}{*}{$\begin{array}{l}\text { Temperature } \\
\text { of can roll }\end{array}$} & \multirow{3}{*}{$\begin{array}{c}\text { Thickness } \\
\delta \\
\mathrm{nm}\end{array}$} & \multicolumn{4}{|c|}{ Magnetic Properties $\left(\theta=0^{\circ}\right)$} & \multicolumn{2}{|c|}{ Roughness } \\
\hline & & & $\mathrm{He}_{\|}$ & $\mathrm{Br}_{/ /}$ & $\mathrm{Sq}_{/ /}$ & $\mathrm{SFD}_{/ 1}$ & Ra & $\mathrm{Rz}$ \\
\hline & & & $\mathrm{kA} / \mathrm{m}$ & $T$ & & & $\mathrm{~nm}$ & $\mathrm{~nm}$ \\
\hline Sample 1 & $-30^{\circ} \mathrm{C}$ & 56 & 103 & 0.686 & 0.99 & 0.46 & 1.1 & 13.1 \\
\hline Sample 2 & $-30^{\circ} \mathrm{C}$ & 121 & 103 & 0.545 & 0.95 & 0.79 & 1.1 & 13.7 \\
\hline Sample 3 & $-30^{\circ} \mathrm{C}$ & 199 & 114 & 0.410 & 0.89 & 1.23 & 1.1 & 14.8 \\
\hline Sample 4 & $50^{\circ} \mathrm{C}$ & 47 & 111 & 0.578 & 1.00 & 0.39 & 1.0 & 13.3 \\
\hline Sample 5 & $50^{\circ} \mathrm{C}$ & 90 & 105 & 0.549 & 0.95 & 0.44 & 1.2 & 13.2 \\
\hline Sample 6 & $50^{\circ} \mathrm{C}$ & 168 & 111 & 0.507 & 0.89 & 0.67 & 1.2 & 13.6 \\
\hline
\end{tabular}

$\delta$ : Thickness of metal evaporated magnetic layer

$\mathrm{Hc}_{/ /}$: Coercivity force.

$\mathrm{Br}_{/ /}$: Residual magnetic flux density.

$\mathrm{Sq}_{/ /}$: Squareness, defined by $\mathrm{Br}_{/ /} / \mathrm{Bm}_{/ /}$, where $\mathrm{Bm} / /$ is maximun magnetic flux density.

$\mathrm{SFD}_{/ /}$: Switching Field Distribution, defined by $\mathrm{SFD}_{/ /}=\Delta \mathrm{H} / \mathrm{Hc} / /$.

$\Delta H$ is an avarage of half-value widths, where differential curves of major loop of $B$ vs $\mathrm{H}$ show maximun and minimun points.

Table2 より長手方向 $\left(\theta=0^{\circ}\right.$, 各パラメー夕に記号

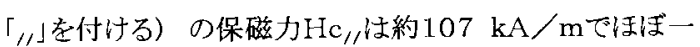
定であった. 膜厚が增加するとキャンロールー $30^{\circ} \mathrm{C}, 50^{\circ} \mathrm{C}$ の場合とも角型比 $\mathrm{Sq}_{/ /}$流減少し, SFD//(Switching Field Distribution)は增加した. Fig. 1に示したように, コラムは 湾曲していることを考慮すれば，厚みが増加すると厚み方 向の異方性が増すと考えられる.そのためそのため， $\mathrm{Sq}_{/}$, SFD„は変化したものと考えられる.

\section{2 磁気特性}

次に，保磁力の印加磁場の方向を，テープの法線を含 む長手方向に広がる面内とし，この面内でテープの長手方 向と印加磁場との角度 $\theta$ を $0^{\circ} \sim 180^{\circ}$ まで変えて保磁力 Hcを測定した. その結果をFig. 6に示す.この結果を塗 布型の媒体と対比して検討する. 塗布型媒体では，長手 配向処理がなされているため単純なモデルとなる. 即ち, 磁性粉末注長手方向に配向し, 磁化の方向は長手方向と 考えてよい, 従って, $\theta=90^{\circ}$ (厚み方向)において, $\mathrm{Hc}$ は極小值をとる ${ }^{8)}$ 。 キャンロールー30 $30^{\circ} \mathrm{C}$ (Fig. 6-( I )) と $50^{\circ} \mathrm{C}$ (Fig. 6-(II))のいずれの場合も，保磁力は $\theta=80$ $\sim 95^{\circ}$ 極大值(極大值Aとする)をとり, $\theta=100 \sim 115^{\circ}$
で極小值(極小值Bとする)をとり，更に $\theta>120^{\circ}$ にて極 大值(極大值Cとする)を示した. Fig. 6より次の点が判る.

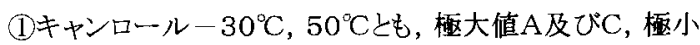
値Bを示守パターンは塗布媒体と同椂 ${ }^{8}$ であった。 塗布 媒体が極小值を示寸 $\theta$ 值 $90^{\circ}$ に対して, 本報の $\theta$ 值が約 $20^{\circ}$ 大きかったが, これは, 塗布型テープでは見られなか った現象で, MEテープでの磁化容易軸が約 $20^{\circ}$ 傾いて いるためと考えられる

(2)キャンロールー $30^{\circ} \mathrm{C} と 50^{\circ} \mathrm{C}$ とを比較すると, 極大值 $\mathrm{A} の$ $\mathrm{Hc}$ 值は $50^{\circ} \mathrm{C}$ 方が $-30^{\circ} \mathrm{C}$ よりも高く, 極大值Aから極小 值Bへの曲線の傾斜は $50^{\circ} \mathrm{C}$ の方が急峻であった.

(3)極小値Bに対応寸る $\theta$ 值の位置に対して, 極大值 $\mathrm{A} と \mathrm{C}$ との対称性はキャンロール $-30^{\circ} \mathrm{C} の$ 方がよく, $50^{\circ} \mathrm{C}$ 場合 には対称性がくずれていた。

上記(2)，(3)よりキャンロール50で作製したテープの方が -30号のテープよりも磁気的な配向が大きい考えられる. これをモデル的に図示寸るとFig. 7のようになる. 即ち, キャンロール50年では, 一斉回転モデルに近い. 即ちコラ ムを形成する磁化ユニット粒子 (Fig. 7のparticle)の磁気 モーメントの方向が揃っている.これに対して, キャンロー ルー30 Cでは, 磁化ユニット粒子の磁気モーメントの方向 は揃っていない。 


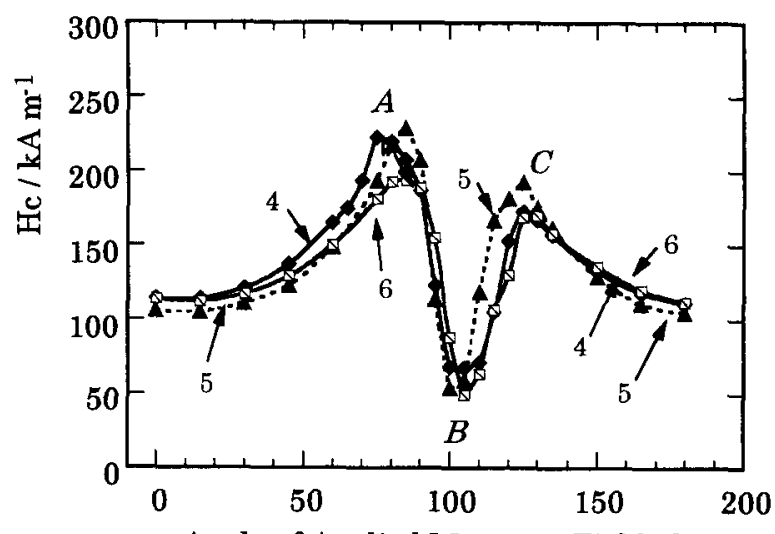

Angle of Applied Magnetic Field /deg

(II) Can Roll: $50 \mathrm{C}$

$\longrightarrow$ Sample $4(50 \mathrm{C}, 47 \mathrm{~nm})$
$\ldots-$ Sample $5(50 \mathrm{C}, 91 \mathrm{~nm})$
$\longrightarrow$ Sample $6(50 \mathrm{C}, 168 \mathrm{~nm})$

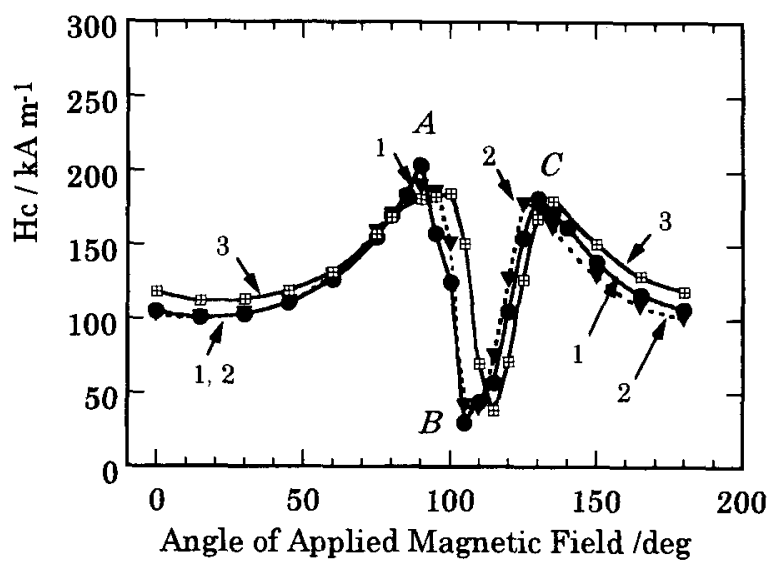

(I) Can Roll: -30 C

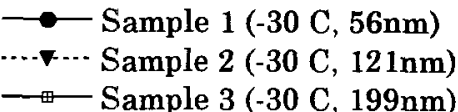

Fig.6 Dependence of coercivity force against direction of applied field.

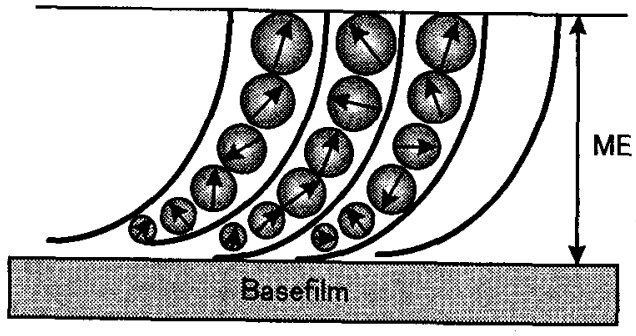

( I ) Can Roll : $-30^{\circ} \mathrm{C}$

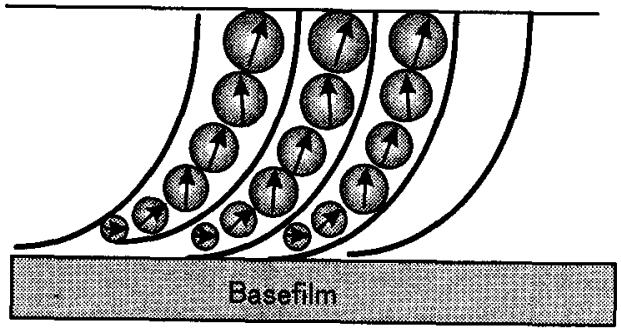

(II) Can Roll : $50^{\circ} \mathrm{C}$

Fig.7 Model of Column Structure.

$\mathrm{ME}$ : Metal evaporated magnetic layer.

O : Particle.

$\rightarrow$ : Magnetic moment.

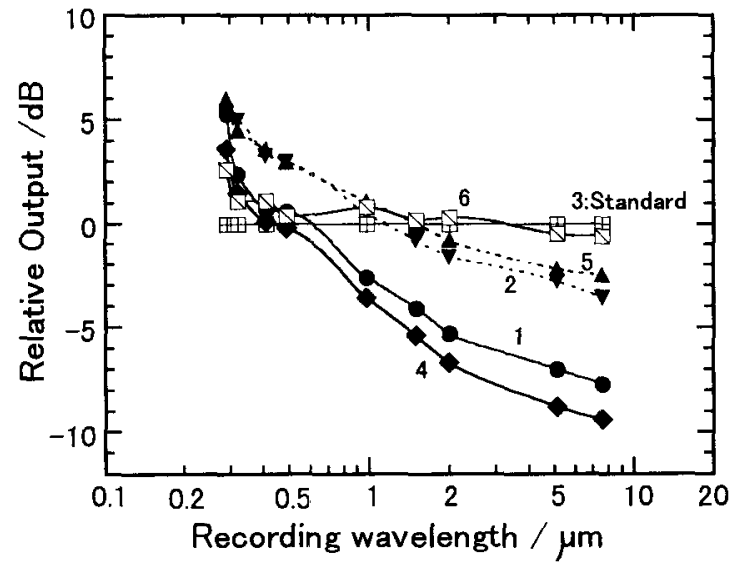

Fig.8 Recording wavelength dependence of output for ME tapes.

The output are expressed as relative values to Sample 3 at respective wavelengths.

The numbers beside respective plots show Sample Number.

$$
\begin{aligned}
& \longrightarrow \text { Sample } 1(-30 \mathrm{C}, 56 \mathrm{~nm}) \\
& \ldots \text { Sample } 2(-30 \mathrm{C}, 121 \mathrm{~nm}) \\
& \longrightarrow \text { Sample } 3(-30 \mathrm{C}, 199 \mathrm{~nm}) \\
& \cdots-\text { Sample } 4(50 \mathrm{C}, 47 \mathrm{~nm}) \\
& \longrightarrow \text { Sample } 5(50 \mathrm{C}, 91 \mathrm{~nm}) \\
& \longrightarrow \text { Sample } 6(50 \mathrm{C}, 168 \mathrm{~nm})
\end{aligned}
$$




\section{3 電磁変換特性}

得られたテープの再生出力の記録波長依存性の測定結 果をFig. 8に示す. Fig. 8では, Sample3(キャンロール $-30^{\circ} \mathrm{C}$, 膜厚 $199 \mathrm{~nm}$ )のテープの各記録波長における出 力在各記録波長での基準值 $(0 \mathrm{~dB})$ 上した。 キャンロール $-30^{\circ} \mathrm{C}, 50^{\circ} \mathrm{C}$ 両条件とも, 数十nm 0 膜厚 (Sample1, Sample4)では短波長域以外では基準のテープよりも出 力が低く，長波長域になるに従い出力が堿少する傾向を 示した. 一方, 150nm以上の膜厚 (Sample3, Sample6) では，逆に長波長域での出力は高くなるが，短波長域での 出力が低いという逆の傾向を示した.また, 約百 $\mathrm{nm}$ の膜厚 (Sample2, Sample5)では，短波長域での出力が高く， 長波長域での出力低下も少なく，バランスの上れた出力特 性であった. Table2に示したようにいずれのテープとも表 面粗さ及び長手方向の保磁力 $\left(\theta=0^{\circ}\right)$ が変わらなかっ た. 従って, 膜厚を $\delta$, 残留磁束密度をBrとすると，長波 長域の出力は $(\delta \cdot \mathrm{Br} \cdot \mathrm{Hc})^{1 / 2}$ に比例するという関㐿 ${ }^{13)}$ が 反映されており，短波長域では厚み損失 ${ }^{14,15)}$ の影響が現 れたと考えられる。

次にキャンロール温度 $-30^{\circ} \mathrm{C}$ と $50^{\circ} \mathrm{C}$ 出力特性老比 較する. Fig. 8より全波長領域においてキャンロール $50^{\circ} \mathrm{C}$

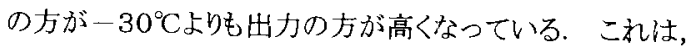
Fig. 7 のモ゙ル図のようにキャンロール50午の方が磁気 的な配向性が揃っていることが一つの理由であると考える. もう一つの理由として，3．1節のFig. 5八の考察で述べた ように温度の高いキャンロール50㕿方が急激な酸化が 起こり，緩やかにコラム全体が酸化された $-30^{\circ} \mathrm{C} の$ 場合上 比べ相対的に酸化層が薄かったことが举げられる. 形成さ れる酸化層は非磁性であるため，スペース損失 ${ }^{14,15)}$ の原 因となったと考えられる.スペース損失Lsの式は下記 (1) 式で表される。

$$
\text { Ls }(\mathrm{dB})=\mathrm{k}(\mathrm{d} / \lambda)
$$

ここで, $\mathrm{k}$ は比例定数, $\mathrm{d}$ は媒体と磁気へッドとの間隔，入 は記録波長である. 式(1)より, キャンロール50 Cの方がd が小さいため, 出力低下が少なく, キャンロールー $30^{\circ} \mathrm{C}$ と 比バ出力值が高かったものと考えられる. 上記のように, 各 サンプルにおいて, 表面粗さは一定であったので, 磁性層 の表面の酸化層 (非磁性)の厚みにより, 上記d值の大小 が決まってくる. 即ち, $-30^{\circ} \mathrm{C} の$ 方が酸化層が厚いため, スペース損失が大きくなり，短波長領域での出力が低下し たものと考えらる.

このことを確認するため, Sample $3\left(-30^{\circ} \mathrm{C}, 199 \mathrm{~nm}\right)$
とSample6 $\left(50^{\circ} \mathrm{C}, 168 \mathrm{~nm}\right)$ について, Auger電子分光 スペクトルの観察を行った. 得られたAuger電子分光スペ クトルをFig. 9に示すが, Sample3, Sample6ともに磁性 層の最表面は酸素濃度が高く, 表面から内部に入るに徉 い酸素濃度が徐々に減少し，Co濃度は緩やかに減少した。 この酸素濃度, Co濃度の変化忙既に報告された結果と一 致する ${ }^{16)}$. エッチングが進むとC原子が急激に多くなり始 める点があるが，ここではCo濃度も減少しており磁性層が エッチングにより消失しベースフィルムが現れたものと考え られる.Fig.9で重要なことは磁性層表面近傍の酸素濃 度が高い領域がSample6ではSample3よりも薄いことで ある.このことより, 表面酸化層の厚みはSample6の方が 薄いことが確認された. 導入された酸素量はキャンロール $-30^{\circ} \mathrm{C}, 50^{\circ} \mathrm{C}$ ほうが，ME層表面で，より選択的に酸素が消費され，酸化 層の厚みが薄くなったものと考えられる.

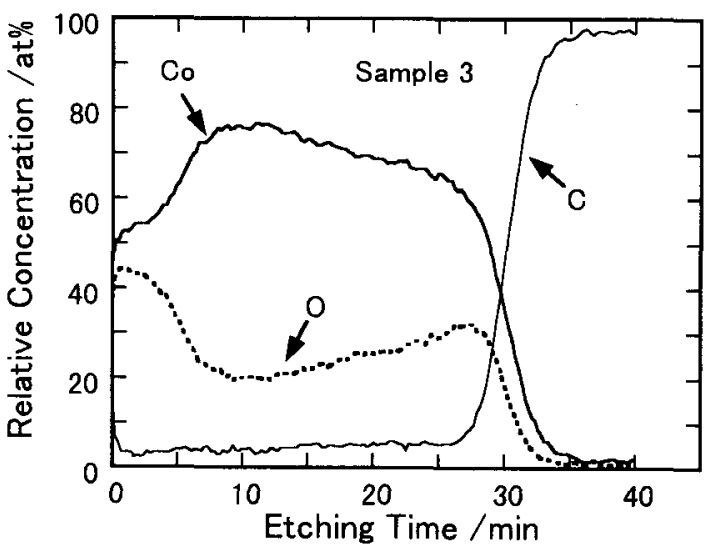

( I ) Can Roll: $-30^{\circ} \mathrm{C}$

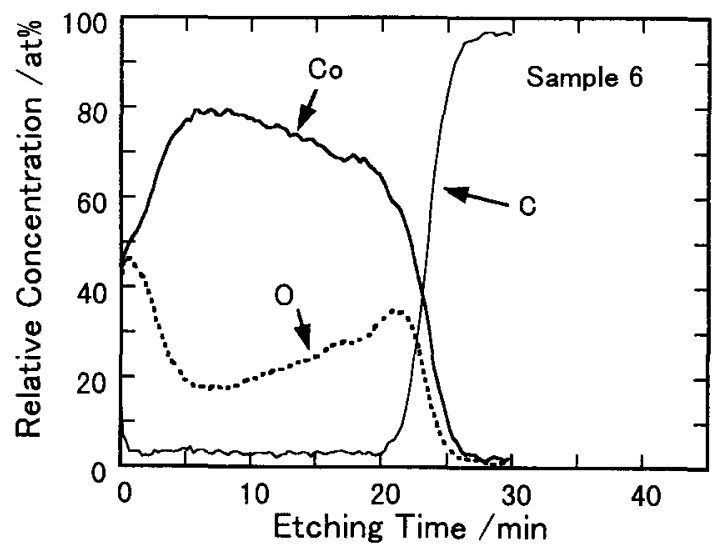

(II) Can Roll: $50^{\circ} \mathrm{C}$

Fig.9 Auger electron spectroscopy of ME tapes. 


\section{4 まとめ}

蒸着時のキャンロール温度を $-30^{\circ} \mathrm{C}, 50^{\circ} \mathrm{C}$ 条件に にて, 蒸着テープを作製したところ, $50^{\circ} \mathrm{C} の$ 方がー $30^{\circ} \mathrm{C}$ りも出力特性が良好であった。これは，50 Cのほうが， (1)ME層のコラム棈造の磁気的な配向性が高いため, およ び，(2)表面の酸化層の厚みが薄いための二つの効果が働 いたためと考えられる. また, ME層膜厚は約 $100 \mathrm{~nm}$ の場 合に全記録波長域の出力特性のバランスが優れていた.

\section{文 献}

1）川野則和, テレビジョン学会誌, 45, 1501 (1991).

2）中村慶久，日本忘用磁気学会誌，17，768 (1993).

3）北原㩽行, Fujifilm Res. \& Develop., 38, 43 (1993).

4）日経ビジネス，9月11日号，73(1995).

5）吉成次郎, 樋口則夫, 粉末治金, 42, 702 (1995).

6) 高井充, 小林康二, テレビジョン学会誌, 44, 1203 (1990).

7) T. Kawana, S. Onodera and T. Samoto, IEEE Trans
MAG., 31, 2865 (1995).

8）成瀬宏治, 館野安夫, 佐藤孝典, 佐藤研一, 千葉一 信, 佐々木利一，信学技報，MR90-7, 43 (1990).

9）传藤研一，千葉一信，伊藤坏哉，佐々木利一, 法橋 次郎, 信学技報, MR90-19, 17 (1990).

10）恒木啓三, 法灀炊郎, 信学技報, MR91-5, 1 (1991).

11) N. Kitaori, O. Yoshida and H. Mizunoya, Jpn. J. Appl. Phys., 36, 6742 (1997).

12）高山孝信, 吉田和悦, 矢野亮, 信学技報, MR90-8, 51 (1990).

13) D. E. Speliotis and J. R. Morrison, IBM J., 10, 233 (1966).

14）松本光功，磁気記録，共立出版侏， p.114 (1984).

15）横山克哉, 磁気記録入門, 粉合電子出版社, p.77 (1992).

16）佐藤研一，近藤洋文，千葉一信，関野智之，海老根 義人, 佐々木利一, テレビジョン学会技術報告, ITEJ Technical Report, 33, 19 (1989). 